\title{
Distribusi Lamun di Zona Intertidal Tanjung Bilik Taman Nasional Baluran Menggunakan Metode GIS (Geographic Information System)
}

\author{
(Distribution of Seagrasses in Intertidal Zone Tanjung Bilik Baluran National Park \\ by Using GIS (Geographic Information System) Methods)
}

\author{
Alhabsy Hidayatullah, Sudarmadji, Fuad Bahrul Ulum, Hari Sulistiyowati, Rendy Setiawan \\ Jurusan Biologi, Fakultas Matematika dan Ilmu Pengetahuan Alam, Universitas Jember (UNEJ) \\ Jln. Kalimantan 37, Jember 68121 \\ E-mail: csalhabsyspd@gmail.com
}

\begin{abstract}
Abstrak
Zona intertidal merupakan wilayah perairan laut yang masih dipengaruhi oleh pasang surut air laut. Salah satu keanekaragaman hayati yang terdapat di zona intertidal adalah lamun. Salah satu tanjung yang memiliki padang lamun adalah Tanjung Bilik Taman Nasional Baluran. Tujuan dari penelitian ini adalah mengetahui distribusi lamun di Zona Intertidal Tanjung Bilik Taman Nasional Baluran dengan menggunakan metode GIS (Geographic Information System). Metode pengambilan data yang digunakan yaitu metode jelajah. Data koordinat habitat lamun dipetakan menggunakan program arcGIS 10. Berdasarkan penelitian yang telah dilakukan ditemukan empat jenis lamun dengan urutan dari distribusi terluas, yaitu Thalassia hemprichii, Enhalus acoroides, Halophila minor, dan Halodule pinifolia. Thalassia hemprichii dan Enhalus acoroides memiliki pola distribusi acak. Halophila minor dan Halodule pinifolia memiliki pola distribusi mengelompok.
\end{abstract}

Kata Kunci: Distribusi, Lamun, Zona Intertidal, Tanjung Bilik

\section{Abstract}

Intertidal zone is marine waters areas that still affected by marine tide. Seagrasses is one of the biodiversity that can be found in intertidal zone. One of location that has seagrass beds is Tanjung Bilik at Baluran national Park. The purpose of this research was to determine the distribution of seagrass in Intertidal Zone Tanjung Bilik-Baluran National Park. The survey method was used to collect data by using Geographical Positioning System (GPS). Each seagrass species found were delineated to get information of its position and substrate. ArcGIS 10 software were used to digitize the species distributions. There were four seagrasses species collected from the area which were Thalassia hemprichii, Enhalus acoroides, Halophila minor, and Halodule pinifolia. Thalassia hemprichii and Enhalus acoroides have random distribution pattern, while Halophila minor and Halodule pinifolia have clumped distribution patterns.

Keywords: Distribution, Seagrass, Intertidal Zone, Tanjung Bilik

\section{PENDAHULUAN}

Zona intertidal merupakan wilayah perairan laut yang masih dipengaruhi oleh pasang surut air laut [1]. Zona ini memiliki keanekaragaman hayati yang lebih besar daripada zona subtidal [2]. Salah satu keanekaragaman hayati yang terdapat di zona intertidal adalah lamun (seagrass) [3].

Lamun merupakan tumbuhan angiosperm akuatik yang beradaptasi hidup terbenam di dasar perairan laut dangkal [4]. Lamun sering hidup berkelompok sampai menutupi dasar perairan laut dangkal, sehingga sering disebut juga dengan padang lamun [5].

Luas Padang lamun di Indonesia sekitar $30.000 \mathrm{~km}^{2}$ [6]. Tetapi, luas padang lamun ini semakin lama semakin berkurang. Berkurangnya luas padang lamun dapat terjadi karena kurangnya pengetahuan masyarakat tentang peran dari ekosistem padang lamun, sehingga tidak ada upaya untuk melindungi dan mejaga ekosistem padang lamun [5].

Padang lamun memiliki peranan yang sangat penting baik secara ekologi dan ekonomi. Secara ekologi lamun berperan sebagai penyedia nutrisi, tempat pemijahan, dan tempat berlindung bagi biota yang hidup di sekitar lamun
[7]. Secara ekonomi lamun digunakan sebagai bahan dasar kerajinan, bahan pembuatan kertas, dan obat-obatan. Selain itu, padang lamun juga berfungsi sebagai daerah tangkapan ikan, karena keberadaan lamun di suatu perairan laut menjadi penyedia nutrisi bagi ikan, sehingga meningkatkan produktivitas ikan [8].

Salah satu tanjung yang memiliki padang lamun di zona intertidalnya adalah Tanjung Bilik Taman Nasional Baluran. Berdasarkan informasi dari petugas Taman Nasional Baluran, bahwa penelitian tentang lamun di Tanjung Bilik masih sangat terbatas, terutama penelitian mengenai distribusinya. Berdasarkan latar belakang tersebut perlu dilakukan penelitian distribusi lamun di Tanjung Bilik yang ditampilkan kedalam suatu peta sehingga dapat diketahuai luasan habitat, persebaran lamun, dan kondisi padang lamun di tanjung tersebut.

\section{METODE PENELITIAN}

\section{Lokasi dan Waktu Penelitian}

Penelitian ini dilakukan di Zona Intertidal Tanjung Bilik Taman Nasional Baluran pada koordinat antara $7^{\circ} 45^{\prime} 6.96^{\prime \prime}$ 
LS dan $114^{\circ} 22^{\prime} 26.36^{\prime \prime}$ BT sampai $7^{\circ} 45^{\prime} 0.26^{\prime \prime}$ LS dan $114^{\circ} 22^{\prime} 8.87^{\prime \prime}$ BT. Pengambilan sampel lamun dilakukan saat surut maksimal (bulan purnama) pada Bulan Mei 2016. Identifikasi spesimen lamun sampai tingkat jenis dilakukan di Laboratorium Ekologi Jurusan Biologi Fakultas Matematika dan Ilmu Pengetahuan Universitas Jember. Selanjutnya dilakukan verifikasi dan validasi di Pusat Penelitian Oseanografi LIPI Jakarta. Analisis data dilakukan di Laboratorium Ekologi Jurusan Biologi Fakultas Matematika dan Ilmu Pengetahuan Alam Universitas Jember.

\section{Alat dan Bahan}

Alat yang digunakan dalam penelitian ini yaitu, roll meter, refraktometer Atago, termometer, GPS Garmin 64 csx, kamera Nikon D3100, tiang pancang, penggaris, metlein $1 \mathrm{~m}$, alat tulis, jarum, pres herbarium, oven, dan buku identifikasi lamun [9], [10], dan [11].

Bahan yang digunakan dalam penelitian ini yaitu alkohol $70 \%$, kantung plastik, tali rafia, kardus, kertas koran, benang nilon, dan kertas label.

\section{Pengambilan Data}

Pertama, dilakukan pemetaan lokasi penelitian dengan cara menandai lokasi penelitian dengan cara mendeleniasi lokasi penelitian.

Kedua, dilakukan pengambilan data lamun memakai metode jelajah (road sampling) (Gambar 1). Penjelajahan dilakukan mulai dari tubir sampai menuju pantai. Lokasi ditemukan lamun ditandai dengan GPS. Spesimen lamun yang didapat lalu diambil gambarnya, diawetkan dengan alkohol 70\% dan dibuat herbariumnya.

Ketiga, dilakukan pencatatan data lingkungan yaitu suhu, intensitas cahaya, salinitas, dan substrat. Ketiganya diukur secara acak sistematis di dalam lokasi penelitian (Gambar 1). Setiap lajur terdapat lima titik pengambilan data lingkungan yang ditentukan secara acak. Pengambilan data abiotik dimulai dari pukul 13.00-17.00 WIB dengan pengulangan sebanyak tiga kali. Suhu diukur menggunakan termometer batang dengan cara dicelupkan pada kedalaman $10 \mathrm{~cm}$. Salinitas diukur menggunakan refraktometer. Substrat diamati dan diambil pada setiap ditemukannya lamun menggunakan "hand-texture" kemudian sampel substrat dibawa ke laboratorium untuk diamati lebih lanjut menggunakan segitiga tekstur tanah.

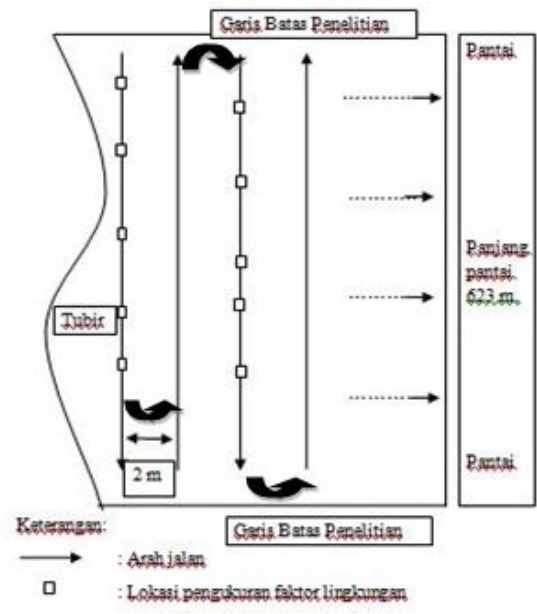

Gambar 1. Skema Road Sampling Lamun dan Pengukuran Faktor Abiotik di Lokasi Penelitian.

\section{Analisis Data}

Pertama, dilakukann identifikasi lamun sampai tingkat jenis di Laboratorium Ekologi Jurusan Biologi Fakultas Matematika Ilmu Pengetahuan Alam Universitas Jember dengan cara mencocokkan ciri-ciri morfologi lamun dengan foto, gambar, dan buku panduan identifikasi lamun [9], [10], dan [11]. Kemudian dilakukan verifikasi dan validasi hasil identifikasi ke Pusat Penelitian Oseanografi LIPI Jakarta.

Kedua, Data koordinat habitat lamun dipetakan menggunakan program arcGIS 10. Titik koordinat hasil deleniasi lokasi penelitian diinput kedalam program arcGIS 10, sehingga akan terbentuk layout peta lokasi penelitian. Titik koordinat ditemukannya jenis lamun diinput kedalam program arcGIS 10, setelah itu dilakukan layering pada tiap titik koordinat jenis lamun yang didapatkan sehingga akan terbentuk peta distribusi tiap jenis lamun. Hasil akhirnya berupa peta tematik distribusi jenis lamun di Tanjung Bilik Taman Nasional Baluran.

Ketiga, dilakukan analisis data lingkungan.Data lingkungan yang ditemukan kecuali substrat dianalisis secara deskriptif sebagai data pendukung distribusi lamun. Substrat yang ditemukan dianalisis menggunakan segitiga tekstur tanah.

\section{HASIL PENELITIAN}

Lamun di Zona Intertidal Tanjung Bilik Taman Nasional Baluran memiliki luasan distribusi yang berbedabeda. Lamun jenis Thalassia hemprichii memiliki distribusi paling luas, diikuti oleh Enhalus acoroides, Halophila minor, dan terakhir Halodule pinifolia (Tabel 1). Luasnya distribusi Thalassia hemprichii dipengaruhi oleh lingkungan yang sesuai untuk kelangsungan hidup lamun ini, terutama substrat sebagai tempat tumbuh (Tabel 2). Adanya variasi substrat menentukan komposisi lamun yang tumbuh [19].

Tabel 1. Komposisi Jenis Lamun di Tanjung Bilik Baluran

\begin{tabular}{lcc}
\hline \multicolumn{1}{c}{ Jenis Lamun } & Luas Area $(\mathrm{m} 2)$ & Luas $(\%)$ \\
\hline T. hemprichii & 12658,82 & 80,20 \\
\hline E. acoroides & 2403,893 & 15,23 \\
\hline H. pinifolia & 468,368 & 2,97 \\
H.minor & 252,363 & 1,60 \\
\hline \multicolumn{1}{c}{ Total } & $15.783,5$ & 100 \\
\hline
\end{tabular}

Tabel 2. Hasil Pengukuran Faktor Lingkungan

\begin{tabular}{lcccc}
\hline \multirow{2}{*}{ Jenis Lamun } & \multicolumn{4}{c}{ Faktor Lingkungan } \\
\cline { 2 - 5 } & $\begin{array}{c}\text { Suhu } \\
(0 \mathrm{C})\end{array}$ & $\begin{array}{c}\text { Salinitas } \\
(0 / 00)\end{array}$ & $\begin{array}{c}\text { Intensitas } \\
\text { cahaya (Lux) }\end{array}$ & $\begin{array}{c}\text { substra } \\
\mathrm{t}\end{array}$ \\
\hline T. hemprichii & 31 & 35 & 1810 & $\mathrm{P}, \mathrm{PK}$ \\
\hline E. acoroides & 31 & 35 & 1810 & $\mathrm{P}, \mathrm{L}$ \\
\hline H. pinifolia & 31 & 35 & 1810 & $\mathrm{~L}$ \\
\hline H. minor & $31-33$ & 35 & $1470-2420$ & $\mathrm{P}, \mathrm{L}$ \\
\hline Keterangan
\end{tabular}

Keterangan: P: Pasir; PK: Pasir Berkarang; L: Lumpur

Berdasarkan Tabel 2, setelah dilakukan pengukuran faktor lingkungan, suhu di Zona Inetrtidal Tanjung Bilik berkisar antara $31-33^{0} \mathrm{C}$. Suhu tersebut sedikit melebihi 
suhu optimum untuk tumbuh, tetapi masih dalam toleransi lamun. Lamun dapat tumbuh dengan baik pada kisaran suhu 23-32 ${ }^{0} \mathrm{C}$ [12]. Pendapat lain juga menyatakan suhu optimum untuk lamun berfotosintesis berkisar $25-35^{\circ} \mathrm{C}$ [13]. Nilai pengukuran intensitas cahaya yang didapatkan berkisar antara 1470-2420 Lux, dengan intensitas tersebut cahaya sudah sampai ke dasar perairan tempat lamun tumbuh dan berkembang. Nilai pengkuran dari salinitas yaitu sebesar $35 \%$ dan merupakan salinitas optimum dalam mentoleransi kadar garam. Nilai optimum toleransi lamun terhadap salinitas adalah $35 \%$ [14]. Zona intertidal Tanjung Bilik memiliki beberapa jenis substrat yaitu, pasir, pasir berkarang, batu karang, dan lumpur. Substrat yang ditumbuhi lamun yaitu pasir, pasir berkarang, dan lumpur. Batu karang tidak ditumbuhi lamun karena akar lamun tidak mampu menembus batu karang yang keras.

Berdasarkan titik koordinat ditemukannya lamun dapat diketahui pula pola distribusinya. Pola distribusi organisme di alam dapat dibedakan menjadi tiga pola yaitu seragam, acak, dan mengelompok [15].

\section{Distribusi Thalassia hemprichii}

Thalassia hemprichii memiliki distribusi terluas diakarenakan adanya kesesuaian dengan kondisi lingkungan terutama substrat. Pada lokasi penelitian, Thalassia hemprichii ditemukan tumbuh pada substrat pasir dan pasir berkarang. Thalassia hemprichii tumbuh pada pasir dan patahan karang [16]. Area substrat pasir dan pasir berkarang merupakan yang terluas di Zona Intertidal Tanjung Bilik Taman Nasional Baluran. Selain itu, Thalassia hemprichii memiliki struktur morfologi yang menguntungkan dalam mempercepat distribusinya. Thalassia hemprichii memiliki rimpang yang kuat dan panjang sehingga mampu menutupi area lebih luas daripada lamun yang lainnya. Thalassia hemprichii juga memiliki akar yang lebih besar dan kuat daripada lamun yang lainnya sehingga mempermudah dalam penyerapan nutrisi dan menembus substrat. Daun Tahalassia hemprichii memiliki ukuran terpanjang dan terbesar kedua setelah Enhalus acoroides, sehingga mempengaruhi kerapatan dan penutupan area.

Thalassia hemprichii secara umum memiliki pola distribusi acak (Gambar 2). Pada Gambar 3 dapat dilihat jika Thalassia hemprichii ditemukan tumbuh secara acak menempati hampir seluruh lokasi penelitian. Pola distribusi acak ini diduga karena adanya persamaan kondisi lingkungan sehingga tiap individu Thalassia hemprichii memiliki kesempatan yang sama untuk tumbuh di area tersebut. Pola distribusi secara acak terjadi apabila individu memiliki kesempatan yang sama untuk menempati setiap titik pada habitat [17].

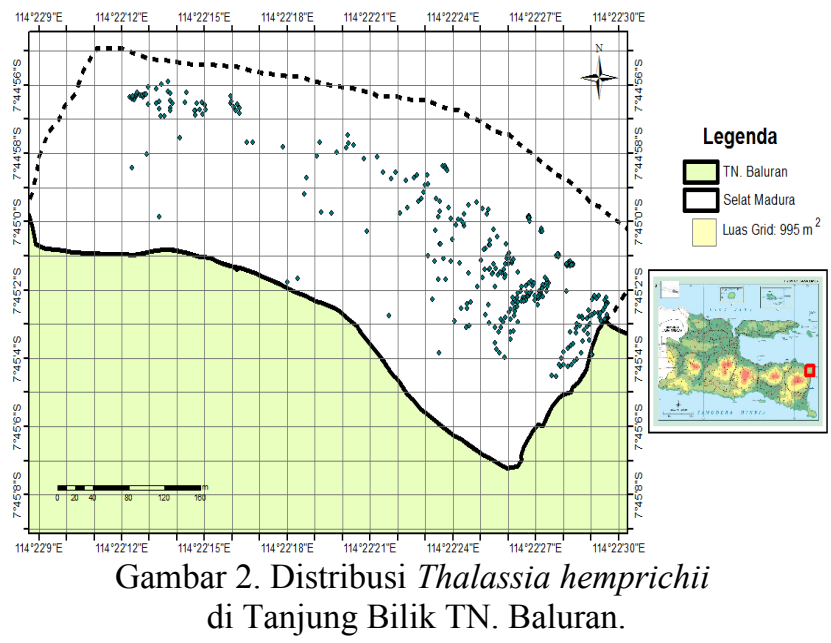

\section{Distribusi Enhalus acoroides}

Enhalus acoroides memiliki distribusi terluas kedua setelah Thalassia hemprichii. Pada lokasi penelitian lamun jenis Enhalus acoroides ditemukan tumbuh pada substrat pasir dan lumpur. Peneliti lain juga menyatakan Enhalus acoroides tumbuh pada subtrat berpasir dan berlumpur [18]. Selain itu, persebaran atau distribusi Enhalus acoroides juga dipengaruhi oleh struktur morfologinya [5]. Enhalus acoroides memiliki akar yang besar dan kuat, sehingga mempermudah dalam penyerapan nutrisi di perairan dan menembus substrat, sehingga pertumbuhannya lebih cepat. Daunnya lebih panjang dan besar daripada jenis lamun yang lain, sehingga area yang tertutupi lebih luas. Tetapi, Enhalus acoroides memiliki rimpang yang lebih pendek daripada Thalassia hemprichii, sehingga pertumbuhan secara horizontal kurang maksimal, sehingga pesebarannya tidak seluas Thalassia hemprichii.

Enhalus acoroides memiliki pola distribusi acak (Gambar 3). Pola distribusi acak pada Enhalus acoroides diduga disebabkan oleh kondisi lingkungan yang sesuai dengan syarat tumbuh Enhalus acoroides, sehingga tiap individu dari Enhalus acoroides memiliki kesempatan yang sama untuk tumbuh dan berkembang menempati setiap titik pada habitat. Distribusi secara acak terjadi karena adanya faktor lingkungan yang seragam atau homogen, tidak adanya persaingan dan tidak adanya kecenderungan untuk mengelompok pada populasi [15]. Substrat pasir ditemukan cukup luas di lokasi penelitian, sehingga menjadi pendukung untuk distribusi lamun Enhalus acoroides karena distribusi lamun spesifik terhadap substrat [19]. Substrat pasir dan pasir berlumpur merupakan lingkungan yang cocok sebagai tempat tumbuh Enhalus acoroides [20]. Selain itu, gerakan air juga mempengaruhi persebaran Enhalus acoroides secara acak. Distribusi biji lamun Enhalus acoroides dibantu oleh air laut, biji tersebut akan terbawa arus dan akan tumbuh pada lingkungan yang sesuai. 


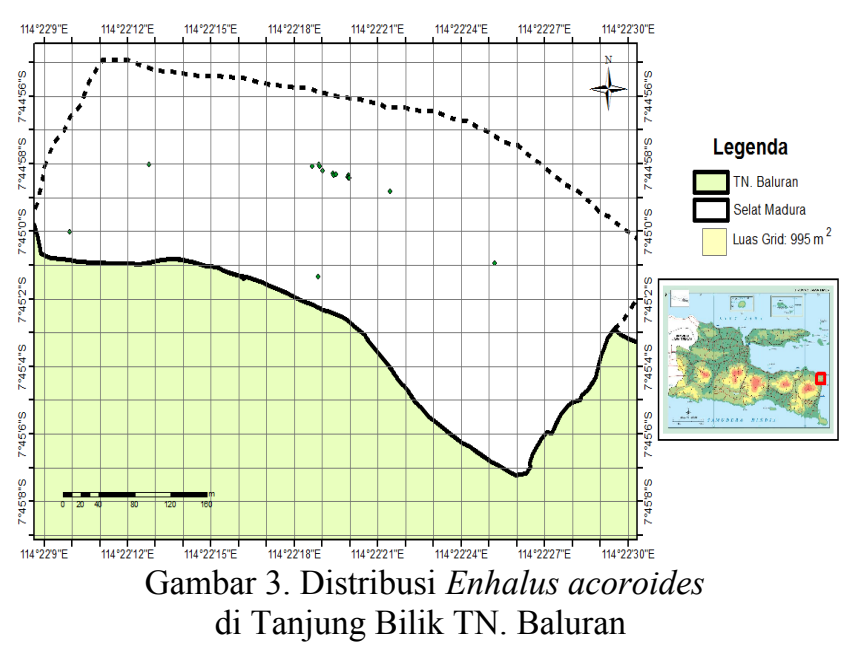

\section{Distribusi Halodule pinifolia}

Halodule pinifolia memiliki area distribusi terluas ketiga setelah Thalassia hemprichii dan Enhalus acoroides. Pada lokasi penelitian Halodule pinifolia ditemukan pada area berlumpur dekat dengan mangrove. Kelompok Halodule ditemui tumbuh di substrat berlumpur dan berdekatan dengan mangrove [21]. Substrat berlumpur merupakan area paling sempit yang ditemukan di lokasi penelitian yang letaknya di sebelah barat lokasi peneilitian. Distribusi Halodule pinifolia tidak terlalu luas dipengaruhi juga oleh ukuran tubuh dan morfologinya [5]. Halodule pinifolia memiliki akar serabut yang berukuran pendek, kecil, tipis, dan halus. Akar ini mampu menembus pada substrat yang halus, seperti lumpur [21]. Daun dari Halodule pinifolia juga berukuran kecil dan memanjang seperti jarum, sehingga kerapatan dan tutupan areanya tidak maksimal. Selain itu, rimpang dari Halodule pinifolia berukuran kecil dan pendek, sehingga pertumbuhan secara horizontalnya tidak begitu pesat. Genus Halodule termasuk lamun pionir [22], [23], dan [24]. Lamun pionir ini ditemukan tumbuh pada substrat yang halus untuk menstabilkan substrat [25]. Substrat yang halus ini mudah terpengaruh oleh aliran arus dan ombak besar saat musim tertentu yang kemudian mengakibatkan tercabutnya dan tertimbunnya lamun sehingga luas distribusinya mengalami penyempitan [25].

Halodule pinifolia memiliki pola distribusi mengelompok (Gambar 4). Pola distribusi mengelompok ini disebabkan karena perbedaan kondisi lingkungan, terutama substrat. Halodule pinifolia ditemukan tumbuh di substrat lumpur. Oleh karena itu, distribusi Halodule pinifolia mengelompok pada substrat yang sesuai yaitu lumpur. Penyebaran horizontal lamun dipengaruhi oleh karakteristik substrat dan gerakan air [2]. Halodule pinifolia hidup mengelompok pada substrat berlumpur. [26] Selain itu, penyebaran secara mengelompok ini diduga karena Halodule pinifolia cenderung melakukan regenerasi vegetatif menggunakan rimpangnya, sehingga distribusinya mengelompok disekitar lamun tersebut tumbuh.

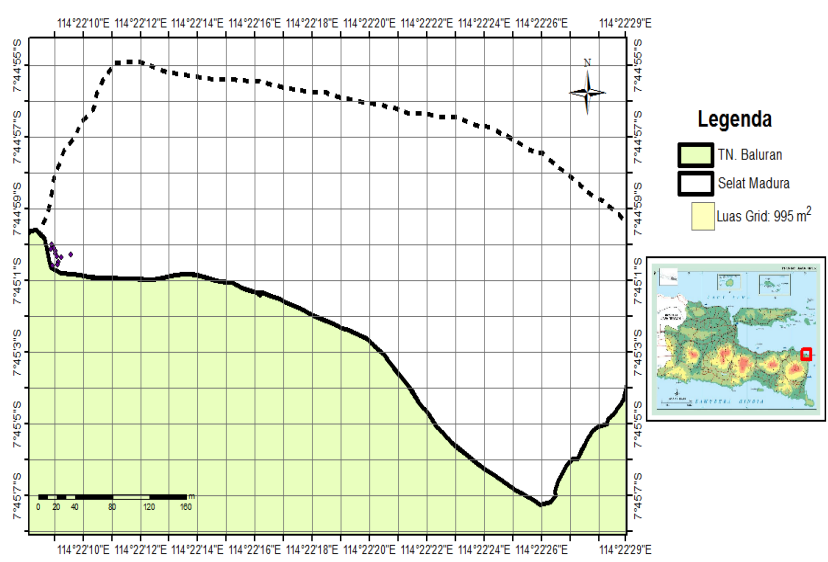

Gambar 4. Distribusi Halodule pinifolia di Tanjung Bilik TN. Baluran

\section{Distribusi Halophila minor}

Lamun dengan distribusi paling sempit yaitu Halophila minor. Lamun jenis ini ditemukan pada substrat berlumpur dan berpasir. Halophila minor tumbuh pada substrat berpasir dan dapat juga dijumpai di substrat berlumpur [27]. Halophila minor memiliki akar yang pendek dan halus. Akar yang pendek dan halus menyebabkan munculnya keterbatasan dalam penyerapan nutrisi, karena akarnya hanya akan mendapatkan nutrisi didekat tempat tumbuhnya dan tidak dapat menyerap nutrisi lebih jauh lagi. Akar ini hanya mampu menembus pada substrat yang halus dan lunak, sehingga Halophila minor tidak ditemui tumbuh di substrat yang lebih keras. Daun dari Halophila minor juga berukuran kecil. Ukuran daun yang kecil ini mempengaruhi luas tutupan pada area distribusinya. Tutupan dan kerapatan lamun dipengaruhi oleh bentuk morfologinya [5]. Selain itu, Halopila minor juga termasuk lamun pionir [25], sehingga memiliki keterbatasan yang sama seperti Halodule pinifolia dalam memperluas distribusinya. Berdasarkan batasan tersebut menyebabkan distribusi Halophila minor tidak seluas jenis lamun yang lain.

Halophila minor memiliki pola distribusi cenderung mengelompok (Gambar 5). Sebagian besar Halophila minor mengelompok karena adanya kondisi lingkungan yang berbeda. Adanya perbedaan substrat menyebabkan perbedaan lamun yang tumbuh. Halophila minor ditemukan tumbuh di substrat berpasir dan berlumpur [27]. Oleh karena itu, Halophila minor hidup cenderung mengelompok pada substrat yang sesuai yaitu berpasir dan berlumpur. Halophila minor merupakan lamun pionir, lamun ini hidup di substrat yang halus di tepi perairan yang fungsinya untuk menstabilkan substrat [25]. Lokasi yang sesuai kriteria tersebut ditemukan di sebelah barat lokasi penelitian berdekatan dengan tepi pantai. Sebagian kecil Halophila minor di Zona Intertidal Tanjung Bilik ditemukan dekat dengan tubir, hal ini diduga karena lamun tersebut terbawa arus dan jatuh pada lingkungan yang sesuai sehingga dapat tetap tumbuh. 


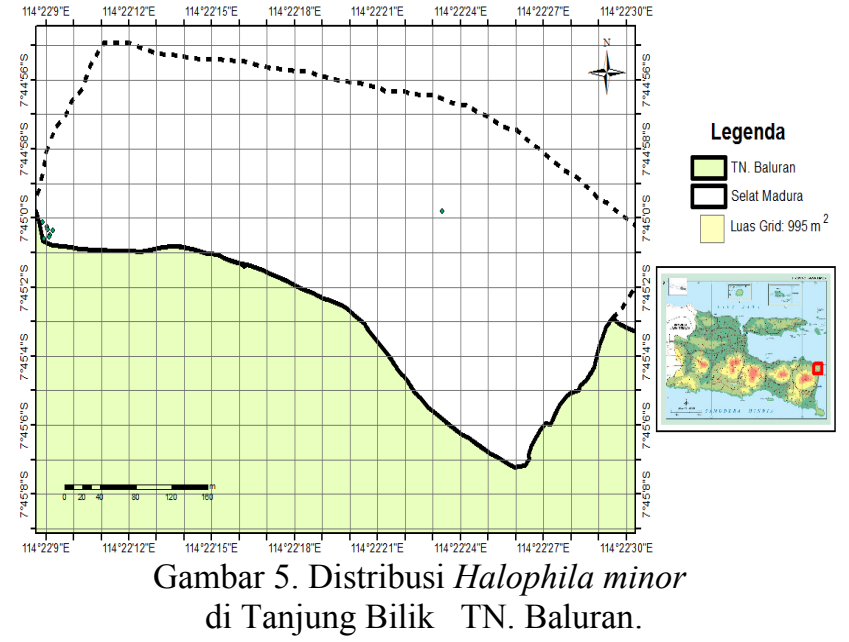

\section{KESIMPULAN}

Distribusi lamun dari urutan terluas adalah Thalassia hemprichii, Enhalus acoroides, Halophila minor, dan Halodule pinifolia. Thalassia hemprichii dan Enhalus acoroides memiliki pola distribusi acak. Halophila minor dan Halodule pinifolia memiliki pola distribusi mengelompok.

Setelah diketahui distribusi lamun di Zona Inetrtidal Tanjung Bilik Taman Nasional Baluran, perlu dilakukan penelitian lebih lanjut terkait dengan interaksi dan peranan lamun dengan biota yang ada disekitar padang lamun. Hal ini untuk melengkapi dan menambah database yang ada sehingga informasi yang didapat semakin lengkap.

\section{DAFTAR PUSTAKA}

[1] Castro, P., dan Huber, M. E. 2003. Marine Biology 4th Edition (4 th). New York: The McGraw-Hill Companies. 462 hal.

[2] Nybakken, 1993. Marine Biology: An Ecological Approach 3th Edition. New York: Herper Collin College Publishers. 496 hal.

[3] Hutomo, M., dan Azkab, M. . 1987. Peranan Lamun di Lingkungan Laut Dangkal, XII(1), 13-23.

[4] Hartog, D. C., and Kuo, J. 2007. "Taxonomy and biogeography of seagrasses." SEAGRASSES: BIOLOGY, ECOLOGY AND CONSERVATION. Springer Netherlands. 1-23.

[5] Hartati, R., Djunaedi, A., Mujiyanto, \& Hariyadi. 2012. Struktur Komunitas Padang Lamun di Perairan Pulau Kumbang , Kepulauan Karimunjawa, 17(4), 217-225.

[6] Green, E. P., dan Short, F. 2004. World Atlas of $S$ eagrasses. Botanica Marina (Vol. 47). Berkeley: University of California Press. http://doi.org/10.1515/BOT.2004.029. 332 hal.

[7] Apramilda, R. 2011. Status Temporal Komunitas Lamun dan Kawasan Rehabilitasi di Pulau Pramukadan Harapan, Kepulauan Seribu, Provinsi DKI Jakarta. Skripsi. Bogor: Institut Pertanian Bogor.

[8] Nainggolan, P. 2011. Distribusi Spasial Dan Pengelolaan Lamun (Seagrass) di Teluk Bakau, Kepulauan Riau. Skripsi. Bogor: Institut Pertanian Bogor.
[9] Lanyon, J. 1986. Seagrasses of the Great Barrier Reef Guide to the Identification of Seagrasses in the Great Barrier Reef. Queensland: Great Barrier Reef Marine Park Authority. 61 hal.

[10] Larkum, A. W. ., Orth, R. J., \& Duatre, C. M. 2006. Seagrasses: Biology, Ecology and Consevation. Netherlands: Springer. 690 hal.

[11] Menez, E. G., Philip R. C., Calumpong, H. P. 1983. Seagrass from The Philippines. Washington: Smithsonian Intitution Press. 48 hal.

[12] Lee, K., Park, S.R., dan Kim Y.K. 2007. Effects of Irradiance, temperature, and Nutrients On Growth D ynamics of Seagrass: A Review. Journal of Experimental Marine Biology and Ecology. 350 (2007) 144-175.

[13] Suhud, M.A., Pratomo, A., dan Yandri, F. 2012. Sruktur Komunitas Lamun di Perairan Pulau Nikoi. Jurnal Umrah.

[14] Pratiwi, R. 2010. Asosiasi Krustasea di Ekosistem Padang Lamun Perairan Teluk Lampung. Ilmu Kelautan vol. 15 (2) 66-76.

[15] Odum E. 1993. Dasar-Dasar Ekologi. Edisi Ketiga. Yogyakarta: Gadjah Mada University Press. 696 hal.

[16] Takaendengan, K dan Azkab, M.H. 2010. Struktur Komunitas Lamun di Pulau Talise. Oseanologi dan Limnologi Indonesia 36 (1): 85-89.

[17] Susanto, P. 2000. Pengantar Ekologi Hewan. Jakarta: Direktorat Jendral Pendididkan Tinggi Departemen Pendidikan Nasional.

[18] Brouns, J dan Heijs, F. 1986. Structural and Functional Aspects of Seagrass Communities and Associated Algae from The Tropical West-Pasific. Nijmegen: Katholieke Universiteit te Nijmegen. 440 hal.

[19] Hasanuddin, R. 2013. Hubungan Antara Kerapatan dan Morfometrik Lamun Enhalus Acoroides Dengan Subsrat Dan Nutrien di Pulau Sarappo Lompo Kab. Pangkep. Skripsi. Makassar: Universitas Hasanuddin.

[20] Yusniati. 2015. Jenis-jenis Lamun di Perairan Laguna Tasilaha dan Pengembangannya sebagai media Pembelajaran Biologi. Jurnal Sains dan Teknologi Tadulako, Vol 4. No 1. Hlm: 13-22.

[21] Sidik, B.P., Harah, M.Z., Pauzi, A.M., dan Madhavan, S. 1999. Halodule Species from Malaysia Diribution and Morphological Variation. Aquatic Botany 5 (1999) 33- 45.

[22] Lefaan, P.T., Setiadi, D. Djokosetiyanto, D. 2013. Struktur Komunitas Lamun di Perairan Pesisir Manokwari. Maspari Journal. Vol. 5 No. 2.

[23] Taurusman, A. A., Isdahartati, Isheliadesti, Ristiani. 2013. Pemulihan Stok dan Restorasi Habitat Teripang: Status ekonomi Lamun di Lokasi Restocking Pulau Pramuka dan Pulau Kelapa Dua, Kepulauan Seribu, Jakarta. Jurnal Ilmu Pertanian Indonesia. Vol. 18(1):1-5.

[24] Juraij, Bengen, D. G., Kawaroe, M. 2014. Keanekaragaman Jenis Lamun sebagai Sumber Pakan Dugong dugon Pada Desa Busung Bintang Utara Kepulauan Riau. Omni-Akuatika Vol. XIII. 
[25] riosambodo, D. 2014. Sebaran Spasial Komunitas Lamun di Pulau Bone Batang Sulawesi Selatan. Jurnal Sainsmat Vol. III No. 2 Hal: 165-175.

[26] Suhenda, E. 2015. Struktur Komunitas Lamun (Seagrass) di Zona Intertidal Pantai Bama Taman Nasional baluran. Skripsi. Jember: Universitas Jember.

[27] Ismail, N. 1993. Preliminary Study of the Seagrass Flora of Sabah, Malaysia. Petranika J. Trop. Abgric. Sci. 16(2): 111-118. 